\title{
Unpacking the Role of Neoliberalism on the Politics of Poverty Reduction Policies in Ontario, Canada: A Descriptive Case Study and Critical Analysis
}

\author{
Jessica K. Gill [D
}

check for updates

Citation: Gill, Jessica K. 2021. Unpacking the Role of Neoliberalism on the Politics of Poverty Reduction

Policies in Ontario, Canada: A

Descriptive Case Study and Critical Analysis. Social Sciences 10: 485. https://doi.org/10.3390/ socsci10120485

Academic Editors: Patrick James and Nigel Parton

Received: 16 October 2021

Accepted: 14 December 2021

Published: 20 December 2021

Publisher's Note: MDPI stays neutral with regard to jurisdictional claims in published maps and institutional affiliations.

Copyright: (C) 2021 by the author. Licensee MDPI, Basel, Switzerland. This article is an open access article distributed under the terms and conditions of the Creative Commons Attribution (CC BY) license (https:// creativecommons.org/licenses/by/ $4.0 /)$.
Department of Sociology and Legal Studies, University of Waterloo, Waterloo, ON N2L 3G1, Canada; jessica.gill@uwaterloo.ca

\begin{abstract}
This paper employs a descriptive case study method to analyze and critically review the emergence of the provincial poverty reduction strategy in Ontario, Canada which was implemented in 2008 and renewed in 2014. The purpose of this study is two-fold: first, it defines the principles of neoliberalism and explores the historical growth of neoliberal thought in Canada, and specifically within Ontario, beginning in the 1980s to the present-day. Drawing on a combination of primary, secondary and grey literature, this paper discusses the ways in which neoliberal ideologies and rhetoric became deeply rooted in political thought and discourse within the province. Employing a critical theory framework, the paper highlights the contrasting ways in which neoliberal values were adopted by the different political parties in power and the detrimental impact this espousal had on individuals living in poverty within Ontario. Second, the paper illustrates the powerful ways in which anti-poverty grassroots movements and social advocacy groups assembled to push for the creation of a provincial poverty reduction strategy. The analysis ends with a critique of the neoliberal influences on the strategy's recommendations and the future outlook of the poverty reduction strategy based on the current political climate within the province.
\end{abstract}

Keywords: neoliberalism; poverty reduction; grassroots movements; Ontario; Canada; social policy

\section{Introduction}

Neoliberalism, as a hegemonic ideology, has played a critical role in shaping Canada's public policy arena both at the federal and provincial levels (Giroux 2004; Raddon 2012). Analysis of political discourses and of the linguistic techniques used to frame policies reveals the tremendous power that neoliberal principles have had on prioritizing specific goals, such as fiscal austerity, on the political agenda. This paper uses a descriptive case study methodology to weave a historical and critical narrative account of the process of neoliberalization in Canada, specifically its development within Ontario and the influence it has had on the construction of poverty reduction policies within the province. Moreover, this paper seeks to explore the role neoliberal ideologies have played in sparking antipoverty movements within the province.

A single case study design is utilized within this article to allow for an in-depth and historically-situated analysis of neoliberalism and its impact on social welfare policies. An advantage of the case study approach is that it provides an extensive and detailed understanding of an intervention or subject of interest which may be too complex to study otherwise (Denzin and Lincoln 2011; Yin 2003). Understanding the influence of a political ideology, such as neoliberalism, on social policies is an example of such a complex and multifaceted phenomenon. The goal of the descriptive case study approach is to explain a phenomenon or an intervention in the specific context in which it occurs (Baxter and Jack 2008; Yin 2003). Data is collected without manipulating any variables or altering the environment; the idea is to get a full, rich, and detailed picture of one subject (Yin 2003). 
The theoretical framework underpinning this case study's analysis is critical theory. At its crux, critical theory seeks to challenge systems of power and domination by questioning the taken-for-granted organization of social life, recognizing the existence of structural inequalities, and grappling with the underlying causes of these inequities (Kincheloe et al. 2018). Critical theory, moreover, highlights the role that political structures play in (re)producing oppression and privilege, with the ultimate aim of uplifting the voices of oppressed groups and decentering privileged ones (Kincheloe et al. 2018). Social justice, empowerment, and emancipation remain fundamental to the ethos of the critical theory paradigm. ${ }^{1}$ The current study utilizes Marxist-informed critical theory to analyze how neoliberal and capitalist values are upheld and legitimized within policy discourses via the imposition of specific ideas, structures, and practices (Azmanova 2020; Kellner 1990). The application of Marxian critical theory is germane to this examination because it helps shed light on the distribution of power in society, particularly between the wealthy and working-classes, and reveals how this power is exercised through social and political dynamics (Azmanova 2020) Particular attention is also paid to the hegemonic ${ }^{2}$ nature of neoliberal thought, that is, its normalization and embeddedness within everyday rhetoric and the subsequent impacts this rhetoric has on the lives of Ontarians living in poverty.

The data sources for this paper draw from a combination of government documents, primary, secondary, and grey literature. An analysis of these sources reveals that the development of neoliberalism and the push for poverty reduction in Ontario can broadly be classified into two stages, beginning with a general shift towards neoliberal policies at the federal level, followed by the subsequent neoliberalization of provincial politics and the growth of provincial anti-poverty grassroots movements. This article seeks to provide a discussion of these two stages and explore how these influences shaped the overall political arena and approaches to poverty-reduction within Ontario, Canada.

\section{Principles of Neoliberalism}

Policy discourse is shaped by political ideology, and one of the dominating ideologies shaping Canada's political arena is neoliberalism. Neoliberal thought developed in the context of the global economic downturn that began in the early 1970s and proliferated internationally through interconnected actors and institutions. Since then, it has led to widespread transformations in the social organization of work, labour relations, and public policies. In the book, A Brief History of Neoliberalism, David Harvey posits that:

Neoliberalism is [ ... ] a theory of political economic practices that proposes that human well-being can best be advanced by liberating individual entrepreneurial freedoms and skills within an institutional framework characterized by strong private property rights, free markets, and free trade. The role of the state is to create and preserve an institutional framework appropriate to such practices. (Harvey 2005, p. 2)

As this passage illustrates, neoliberalism is a theory, or philosophy, of governance which contends that the well-being of a nation and its citizens is best served through free market enterprise; where markets govern the distribution of wealth and where few restrictions are placed on business activities and ownership vis-à-vis strong private property rights (Raddon 2012; Harvey 2005).

Proponents ${ }^{3}$ of neoliberal thought argue that open, competitive, and unregulated markets provide the best mechanism for allocating wealth within any society and that the state should not assume an active role within the functioning of the economy-this tenet is referred to as market fundamentalism (Raddon 2012; Giroux 2004). Alongside this basic definition, there are five central concepts underlying neoliberalism: pro-individualism, freedom of choice, market security, laissez-faire government and minimal state intervention within the market (Larner 2000; Steger and Roy 2010). The first two concepts, pro-individualism and freedom of choice, are often presented by neoliberal adherents as progressive traits that are essential within an increasingly globalized world. Harvey (2005) argues that for 
any ideology to become dominant or hegemonic, as neoliberalism has, it must appeal to the wider population by invoking values, desires and the possibility of new opportunities.

Neoliberalism has carved its niche within the global political arena by arguing that state interventions within the economy and on the lives of autonomous individuals are repressive because they infringe on the principal of human dignity and freedom of choice (Harvey 2005). This implies that under heavy state involvement, collective benefit is held above individual benefit, thereby preventing individuals from realizing their full financial potential (Harvey 2005). The role of the government, according to neoliberal theory, should only be to safeguard the market by maintaining policies that support the dominance of market forces (Harvey 2005; Steger and Roy 2010). Thus, neoliberal ideology advocates for a minimalist non-interventionist state (Larner 2000).

An offshoot of this pro-individualist concept, however, is that citizens are expected to be financially self-reliant, which downplays the state's responsibility in providing social welfare supports to citizens, unless under dire circumstances (Chapell 2006). Those who need these supports are deterred from relying on them and are stigmatized if they do (Kazemipur and Halli 2001; Schram 2019). Stigmatization is exceedingly problematic for those living in poverty because such social supports are needed for survival (Kazemipur and Halli 2001; Schram 2019). In other words, neoliberalism focuses on reorienting the way governments operate such that state policies increasingly favour the interests of the capitalist classes by: (1) eliminating policies and programs that provide economic and social security; (2) increasing the costs of public services such as university tuition, and (3) commodifying/exploiting labour through the systemic devaluation of work and reinforcement of poor, precarious, and dehumanizing working conditions (Azmanova 2020; Thomas 2012, p. 127).

\section{Growth of Neoliberalism in Canada}

Prior to the expansion of neoliberalism within the nation, Canada was characterized by a more generous welfare state with strong social policy programs, similar to many other liberal welfare regimes at that time (Dimand 2019; Esping-Andersen 1990; Raddon 2012; Raphael 2011). The major economic ideology that preceded neoliberal thought was Keynesianism which remained prominent during the post-World War II era that spanned between the 1940s and 1960s (Raddon 2012). Unlike neoliberalism, this economic model focused on increasing state involvement within the economy because it was considered essential to stimulate growth (Raddon 2012). Keynesianism originated in the works of John Maynard Keynes, a British economist, in response to widespread unemployment that occurred during the 1920s and 1930s across Europe and North America (Raddon 2012). Its adoption within Canada and elsewhere was influenced by pressure from working-class movements for economic justice (Raddon 2012). Proponents of this ideology argued that increased social spending on programs by the government during times of economic recession helps maintain stable employment for all citizens and, by proxy, a stable pattern of consumer spending that strengthens the economy (Raddon 2012). Keynesianism is often understood as a compromise between the interests of workers and the interests of the wealthy capitalist classes, which helps maintain rapport between wealthy capitalist class and the working class within the state (Harvey 2005). Central to the Keynesian approach to social policy are the principals of social equality, social integration, and social rights (Raddon 2012).

Under the post-war Keynesian framework, the Canadian federal government introduced several national social-security programs designed to support families and communities by fostering higher wages, decent working conditions, stable employment, and social benefits such as pension plans, unemployment insurance, welfare, and disability benefits (Raddon 2012). Some of these benefits included: the Unemployment Insurance Act (1940) which protected workers in case of injury; family allowances (1945) which were monthly installments intended to support families with children; the Canada Pension Plan (1965) which provided social insurance protection for old age, disability, and survivor's benefits; 
the Medical Care Act (1966), which made healthcare universally accessible; and the Canadian Assistance Plan [CAP] (1966), which was a comprehensive program providing access to a range of social services such as day care, child welfare, and family counselling, with the overarching goal to eliminate conditions giving rise to poverty (Albert and Kirwin 2006; Guest 2006; Ross and Lochhead 2007). Keynesian policies helped achieve steady economic growth within Canada which enabled rising standards of living for the general population (Raddon 2012). With high rates of employment and the development of a strong social safety-net during this period, poverty rates showed a steep decline between the 1950s and 1970s (Sarlo and Walters 2001). This trend, however, began to slow as Canada's social policy terrain shifted from the Keynesian economic ideology to a neoliberal one.

\section{Neoliberalism in the Federal Context}

During the late 1970s and early 1980s, neoliberal thought started to gain prominence in Canada and within other liberal welfare nations due to an increase in globalization and the need to remain competitive within a new economic reality (Dimand 2019; Raddon 2012). The shift away from Keynesianism was an intentional and political one, and served to dismantle the social safety-net in order to fiscally support the wealthy and powerful corporatist agenda. The induction of neoliberalism into Canada was driven by particular interests; a calculated move on behalf of the corporate elite to reassert control over the elements of political and economic life that was lost during the post-war Keynesian era of social intervention (Harvey 2005; Raphael 2011). It signaled the development of transnational corporations, the opening of borders between nations allowing for free trade, and increased migration between countries—events which directly impacted the maintenance of the social welfare state (Bierman et al. 2009). The economic transition ushered in an overall reduction in social citizenship and an emphasis on the advancement of the business sector.

Neoliberalism began its stronghold at the federal level in 1984, when Brian Mulroney of the Progressive Conservative Party was elected Prime Minister (B. Evans 2007). Elsewhere in the liberal-democratic world, similar transformations were occurring. The appointment of Margaret Thatcher as Britain's Prime Minister in the mid-1970s was integral to the spread of neoliberalism across the western world under what is now colloquially called Thatcherism (Harvey 2005; Kivisto 2021). In the United States, the election of President Ronald Reagan of the Republican Party in the 1980s introduced similar policies under the banner of Reaganomics (Harvey 2005; Kivisto 2021). In Canada, Mulroney embraced neoliberal policies but to a lesser extent than was seen in the United States and Britain (Mahon 2008). While Mulroney was in office, policy initiatives were reoriented towards reducing the federal deficit, removing unnecessary subsidies, supporting the private sector through deregulation, and trade liberalization to increase international competitiveness (P. Evans 1996). In true neoliberal style, many of the retrenchments to the welfare state were justified by claims that an economic crisis was looming, and that government spending was excessive, thus making budget cuts seem necessary (Raddon 2012). These changes had a significant impact on the design of social programs. Mulroney's plan revolved around three principal policy changes rooted in neoliberal thinking: social responsibility, fiscal responsibility, and fiscal flexibility (P. Evans 1996).

The principle of social responsibility was based on the notion that scarce resources should only be reserved for those who need it the most. It led to the prioritization of targeted social benefits in place of universal benefits ${ }^{4}$ (P. Evans 1996). As a result, universal programs such as the Family Allowance were eliminated or put in danger under Mulroney's plan and replaced with targeted benefits or tax-credits because these supports were deemed more economical and productive (P. Evans 1996; Habibov and Fan 2007). The second principle of fiscal responsibility was rooted in the neoliberalist understanding that employment is the best form of income security and government expenditure should focus primarily on providing citizens with job opportunities. This ideology prompted cuts to unemployment insurance and establishment of short-term employment programs in 
order to push recipients into the labour market faster, but into increasingly precarious jobs rather than stable ones (P. Evans 1996; Habibov and Fan 2007). Finally, the principle of fiscal flexibility focused on curbing the federal deficit by reducing expenditures on transfer payments ${ }^{5}$ to individuals and provinces which meant less funding for social programs (P. Evans 1996). In short, the principles discussed actively combined to weaken the social safety-net, making it especially difficult for those who were unable to support themselves financially. At the end of Mulroney's tenure in 1993, the rollbacks to the welfare state under the new neoliberal agenda continued with the election of Jean Chrétien and later Paul Martin of Canada's Liberal party in 1993 and 2003, respectively (McBride 2005). The ideological changes at the federal level had an important impact the politics within the individual provinces (see Table 1 for a summary of the federal transition from Keynesianism to neoliberal economic ideology).

Table 1. Summary of the Prime Ministers in power at the federal level in Canada during the Keynesian period to current neoliberal times and the effect on social policy during each phase (Albert and Kirwin 2006; Harvey 2005; Parliament of Canada 2016a).

\begin{tabular}{|c|c|c|c|}
\hline Prime Minister & Political Party in Power & Time Period & Political Ideology and Impact on Social Policy \\
\hline Louis St. Laurent & Liberal & 1948-1957 & \multirow{4}{*}{$\begin{array}{l}\text { Post-World War II Period } \\
\text { - } \quad \text { Marked by Keynesian economic ideology } \\
\text { Introduction of social security and welfare } \\
\text { programs (strengthening the social safety } \\
\text { net) } \\
\text { Unemployment and poverty rates are } \\
\text { generally low }\end{array}$} \\
\hline John Diefenbaker & Progressive Conservative & $1957-1963$ & \\
\hline Lester B. Pearson & Liberal & 1963-1968 & \\
\hline Pierre Elliott Trudeau & Liberal & 1968-1979 & \\
\hline Joe Clark & Progressive Conservative & 1979-1980 & \multirow{3}{*}{$\begin{array}{l}\text { Transition Phase } \\
\text { - } \quad \text { A plateau in social security and welfare } \\
\text { programs occurred } \\
\text { - } \quad \text { Time of economic stagflation } \\
\text { - } \quad \begin{array}{l}\text { Few new social programs or initiatives are } \\
\text { introduced; prior initiatives are maintained }\end{array}\end{array}$} \\
\hline Pierre Elliott Trudeau & Liberal & 1980-1984 & \\
\hline John Turner & Liberal & 1984 & \\
\hline Brian Mulroney & Progressive Conservative & 1984-1993 & \multirow{6}{*}{$\begin{array}{l}\text { Neoliberal Period } \\
\text { - } \quad \text { Characterized by cuts to social spending } \\
\text { and social policy. Laissez-faire government } \\
\text { - Spike in interest in international } \\
\text { competitiveness and international trade } \\
\text { (e.g., NAFTA) } \\
\text { Market fundamentalism/ Market fetishism } \\
\text { increases } \\
\text { - A focus on economic austerity } \\
\text { - Individual responsibility is stressed. The } \\
\text { poor are deemed as undeserving and } \\
\text { "poor-bashing" increases } \\
\text { Privatization and deregulation of services is } \\
\text { stressed }\end{array}$} \\
\hline Kim Campbell & Progressive Conservative & 1993 & \\
\hline Jean Chrétien & Liberal & 1993-2003 & \\
\hline Paul Martin & Liberal & 2003-2006 & \\
\hline Stephen Harper & Conservative & 2006-2015 & \\
\hline Justin Trudeau & Liberal & 2015-present & \\
\hline
\end{tabular}

\section{Neoliberalism and Ontario's Provincial Government}

The adoption of radical neoliberal policies in Ontario is most closely associated with election of Mike Harris's Progressive Conservative party in 1995. However, an analysis of the policies and changes to social programs implemented prior to 1995 indicates that the process of public policy neoliberalization in Ontario actually pre-dates the Harris administration (Fanelli and Thomas 2011). In this section, the origins of neoliberalism within the province and its development over time are discussed. 


\subsection{Post-War Ontario and the Recession: 1943 to 1985}

From 1943 to 1985, Ontario was a province dominated by Progressive Conservative rule (Fanelli and Thomas 2011). The Progressive Conservatives had remained in power uninterrupted over 13 elections and under four premiers, operating from the political center during a period of fiscal prosperity (White 1999). Given the financial stability Ontario maintained over most of the Progressive Conservative's tenure, social welfare programs within the province also remained stable, reflecting the conditions seen federally. This trend gradually started to change in 1975 when slow financial growth, inflation, and fiscal deficit prompted sectors of the government to review public spending and, utilizing typical neoliberal rhetoric, conclude that spending on social programs was out of control and threatened the economic future of Ontario (Maxwell 2009). In response, provincial investments into social programs, such as income supports, were curbed; by the 1980s individuals receiving social assistance found themselves dealing with higher levels of poverty and inadequate living conditions (Maxwell 2009). These cuts, combined with the economic recession of 1981, led to a surge in unemployment rates and an increase in people who actually needed access to these programs (Maxwell 2009).

It was during this time that the Canadian Council of Social Development (CCSD) and social planning councils ${ }^{6}$ across Ontario took an active role in documenting the effects of welfare state retrenchment on the poor, publishing numerous papers on the issue. The Welfare Council of Canada, for example, co-authored a report entitled And the Poor get Poorer: A Study of Social Welfare Programs in Ontario published in 1981, which noted that Ontario's most economically vulnerable citizens were being most negatively impacted by cost-cutting, yet this segment of the population was being systematically ignored by the government (Maxwell 2009). In this way, social planning councils and other nonprofit organizations played a critical role in pushing for poverty reduction and awareness; lighting the way for anti-poverty grassroots movements which became especially visible during Harris's tenure (Maxwell 2009). These mobilizing networks, as will be discussed in detail later on, played a pivotal role in advocating for a poverty reduction strategy in Ontario.

\subsection{Beginnings of Neoliberal Thought: 1985 to 1995}

In the summer of 1985 (coinciding with the election of Mulroney and the subsequent changes to federal social programs) increasing political unrest in Ontario resulted in the Liberal party gaining power under the Premiership of David Peterson (Fanelli and Thomas 2011). The defeat of the Progressive Conservative reign, known as the 'Big Blue Machine', after 42 years in power signaled an important paradigm shift in Ontario (White 1999). This shift marked the beginning of the province's move from its traditional position at the political center towards the political right, a symptom linked to the neoliberalization that was being experienced across Canada (Fanelli and Thomas 2011). It was also during Peterson's time in office that anti-poverty movements began to take shape and became more visible, attempting to counter the retrenchments to Ontario's social safety-net. The Ontario Coalition Against Poverty (OCAP), which is now one of the most vocal anti-poverty advocates in Ontario, began formation in the 1980s and had their first major March Against Poverty to Queen's Park in 1989 during Peterson's tenure (Clarke 2001). OCAP's protest was successful in gaining some changes to social policies; however, the trend towards neoliberal policies continued to expand. 
Peterson's Liberal Party remained in office from 1985 to 1990, after which Ontario's New Democratic Party (NDP) came to power with Bob Rae as Premier. It was the first time in Ontario's history that a social democratic party had been elected (Tanguay 1997). Ironically, it was also during this period that neoliberal policies became even more visible in Ontario (Fanelli and Thomas 2011). The NDP is traditionally associated with the political left, known for its strong support of unions, the working poor, and minority rights. Therefore, the fact that the foundation of Ontario's neoliberalization was laid under the tutelage of a so-called socialist party speaks to the hegemonic nature of neoliberalism as an ideology. This neoliberal turn placed anti-poverty advocacy groups, labour unions, and the working poor at odds with the NDP - a party historically known to place the needs of the working class above corporatist interests. The NDP came into power in the midst of a major recession during the early 1990s, it was an unexpected victory, and it quickly became apparent that they were not completely prepared to run the province (Tanguay 1997).

Bob Rae had run on an electoral platform that emphasized investments in social services, education, healthcare, employment, and infrastructure (Fanelli and Thomas 2011). To fulfill these promises he decided to run on a $\$ 9.7$ billion deficit during the first budget, which business commentators disapprovingly likened to a Keynesian-esque strategy similar to the one seen in the post-war era (McBride 1996; Tanguay 1997). Using the funds, Rae made headway in strengthening wage protection programs for workers (Bill 70); labour relations reform (Bill 40); raising social assistance by 7\%; and shelter allowances by $10 \%$-but fell short in the area of job creation, triggering a negative reaction from the public (Fanelli and Thomas 2011; Maxwell 2009; Tanguay 1997). The provincial deficit ballooned, creating backlash from the conservative opposition and the media who questioned the NDP's socialist agenda and its economic sustainability (Tanguay 1997).

In an attempt to regain popularity, the NDP shifted its focus away from their longstanding commitment to protect the needs of the poor and working-class in favour of protecting the interests of the private business sector, corporations, and middle-class families (Tanguay 1997). They began to embrace austerity and fiscal conservatism with the aim of reducing the deficit and balancing the provincial budget. Rae's government tightened welfare eligibility, stiffened income exemptions on welfare, and reduced support for low-income workers (Maxwell 2009). These changes coincided with federal initiatives that restricted eligibility for unemployment insurance, imposed caps on provincial cost-sharing for the Canada Assistance Plan [CAP], ${ }^{7}$ and made cuts to other social benefits (Maxwell 2009). As the final straw, in 1993, Rae introduced his controversial Social Contract which cut the salaries of civil servants in an effort to decrease public spending (McBride 1996; Tanguay 1997). These changes had a significant impact on the poorest and most marginalized segments of Ontario's population. Worker unions and the labour movement felt increasingly betrayed by the NDP's new neoliberal agenda given that they had been Rae's strongest supporters at the outset of the election (McBride 1996). The NDP government found itself prisoner of hegemonic neoliberal ideologies (see Figure 1 for Ontario's political spectrum). 


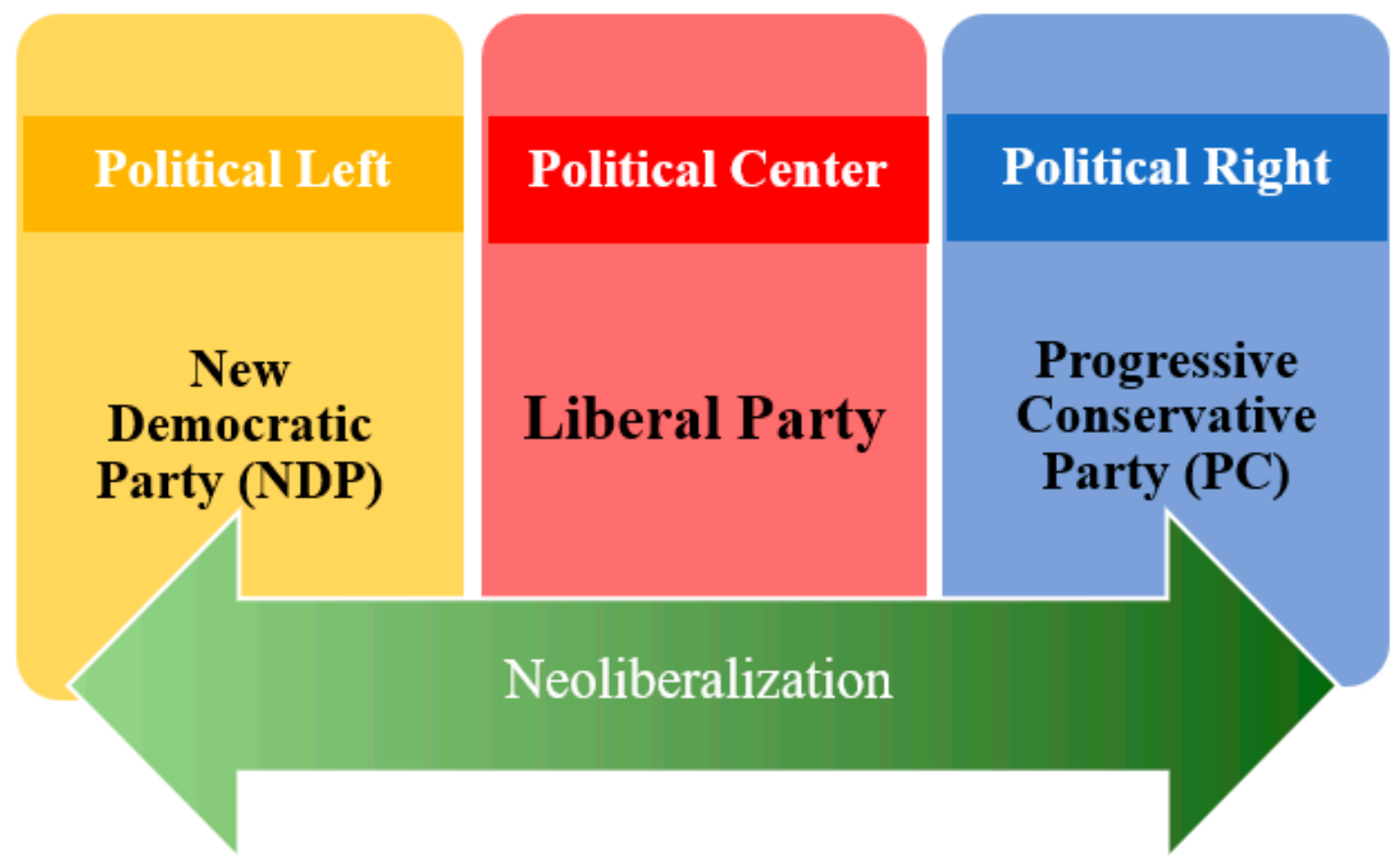

Figure 1. This graphic shows the political spectrum of the three major political parties in Ontario with the NDP falling on the political left, Liberal party positioned at the center and PC party on the right. The green arrow gradient is indicative of the neoliberalization of each party, with the dark end representing a stronger adherence to neoliberal principles.

\subsection{Aggressive Neoliberalization in Ontario: 1995 to 2003}

With increasing opposition to the NDP's policies from the business sector, and alienation from its traditional leftist supporters, the party became fragmented. This gave way to the 1995 election of the Progressive Conservatives under Premier Mike Harris (Tanguay 1997). Though the seeds of neoliberalism had been planted under the NDP's leadership, it was not until Harris' Progressive Conservatives that Ontario experienced its most radical neoliberalization to date. To compare, the Harris government's policies were very different from the policies of the Progressive Conservatives that had, between 1943 and 1985, overseen the development of a number of social programs ${ }^{8}$ (Maxwell 2009). Harris' policies veered dramatically to the political right, running on an orthodox neoliberalist platform of tax-cuts, job creation, enhanced business investment, welfare reform, zero-deficit approach to the provincial budget, and less government intervention (Fanelli and Thomas 2011; Maxwell 2009). He dubbed this the 'Common Sense Revolution' which, on the surface, had a candid appeal to the general public during the elections.

The Harris administration had worked diligently, conducting targeted and extensive public opinion research to uncover hot-button topics that would garner public support (Kozolanka 2010). Using these data, they spun their neoliberal agenda in a positive light to establish their hegemonic policies. Once in power, the speed and range of cuts that Harris' Progressive Conservatives implemented was unprecedented, sending anti-poverty activists into an uproar (Maxwell 2009). In the first year alone, the Harris government carried out massive reductions to health and education spending, closed hospitals, made cuts to childcare subsidies, attacked worker and union rights, and eliminated worker training programs such as JobsOntario and Jumpstart (Fanelli and Thomas 2011; Maxwell 2009; Tanguay 1997). The ultimate goal of the 'Common Sense' approach was to decrease provincial debt and strengthen the economy, even if this was achieved at the expense of Ontario's social services and through the vilification of the poor. The tactics employed by the conservative government reflect the influence of neoliberal ideology. 
The changes Harris implemented coincided with Prime Minister Chrétien's decision to eliminate the CAP in 1995, resulting in deep cuts to provincial cash transfers used to fund social programs (Maxwell 2009). In response to these federal cuts, the Harris government downloaded important fiscal and administrative responsibilities onto municipalities through the Local Services Realignment (LSR) initiative in order to save money and relinquish the province's direct accountability towards the public (Maxwell 2009). Municipalities suddenly found themselves in charge of providing social assistance, public health, and social services to residents, thus shouldering more responsibility than they could effectively handle with the limited funds that they had (Maxwell 2009). Other changes Harris made in lieu of the elimination of CAP included cuts to Ontario's Ministry of Community and Social Services, reductions in public transit, a minimum wage freeze at $\$ 6.85 / \mathrm{h}$ for nine years, a block on building non-profit housing, attacks to the affordable housing market by encouraging ownership over rental, and a reduction in funding for social service agencies (Maxwell 2009). Harris also accelerated the deinstitutionalization of mental health facilities which left many psychiatric patients without shelter (Maxwell 2009). Many of the implemented cuts hit the poorest segments of the population the hardest as they were the most reliant on services such as public transit, affordable housing and social services. For example, the minimum wage freeze did not account for inflation and the price of basic goods, making it very difficult to afford a decent living standard for poor Ontarians.

One of the harshest fiscal changes by Harris, which had a direct bearing on poverty within the province, was his $21.6 \%$ cut to welfare payments under the General Welfare Assistance initiative 9 (Maxwell 2009; Tanguay 1997). Over the course of Harris' tenure, he effectively replaced the General Welfare Assistance program with two programs more closely aligned with the Progressive Conservative's neoliberal agenda: Ontario Works (OW) and Ontario Disability Support Program (ODSP). The new programs placed a heavier emphasis on moving welfare recipients towards employment through the notion of 'workfor-welfare', or workfare-focused policies (Maxwell 2009). The distribution of benefits was made contingent upon one's employment, largely ignoring the overall well-being of recipients and the multitude of factors that contribute to poverty. According to Harris, any able-bodied person should be employed and actively contributing to Ontario's economy to be eligible for benefits, implying that the health of the economy was to be prioritized over the health of individuals. The focus on workfare demonstrates the neoliberal influence underlying OW (Mahon 2008; Maxwell 2009). The Progressive Conservatives argued that the provision of social assistance was wasteful and unaffordable. They justified this by pathologizing the poor and invoking images of welfare recipients as undeserving of assistance, whose personal failings, or lack of motivation, led them to poverty (Fernando and Earle 2011; Maxwell 2009).

Social assistance became a point of contention within the public eye as anxiety and anger mounted against specific groups who were considered undeserving users of the welfare system. These included Indigenous populations, racial minorities, immigrants, incarcerated individuals, teens, single mothers, and other marginalized communities (Tanguay 1997). The Harris government capitalized on this public animosity by enacting more changes that made access to social assistance difficult and inconvenient. For example, a 'spouse in the house' rule was mandated wherein an individual living with another person who earned an income, was automatically disqualified from receiving social assistance payments (Maxwell 2009). Feminist groups and anti-poverty advocates argued that this rule was harmful, especially for women because it left them financially dependent on their partners-sometimes under very precarious and dangerous living arrangements. It also deterred existing recipients from embarking on new relationships in fear of losing benefits (Maxwell 2009). In line with the moral view of poverty Harris also terminated welfare payments for individuals who were in jail, indirectly labelling them as undeserving and deviant members of society (Maxwell 2009). 
To further discourage access to social assistance and to track alleged welfare fraud, the Harris government reinstated mandatory house visits which allowed welfare administers to conduct random checks of recipient's homes legally and without a warrant (Maxwell 2009). This mandate legitimized the invasion of personal privacy, providing an example of how the poor were being wrongfully surveyed, targeted, and victimized under the neoliberal agenda (Maxwell 2009). Furthermore, the Progressive Conservatives introduced a 'Welfare Fraud Hotline' to catch individuals deemed to be abusing the system. Beginning in 2000, those who were convicted of fraud received a lifetime ban from welfare payments and lost a portion of their shelter allowance, leaving many families unable to pay rent (Maxwell 2009). The tightening of eligibility rules for social assistance and changes to the program caused a drop in social assistance recipients between 1995 and 2003 (Fernando and Earle 2011).

The attack against the poorest segments of Ontario's population was not limited to cutting social assistance and public services, the Progressive Conservatives also directly targeted the poor through legal measures. For example, Ontario's Safe Streets Act, which came into effect in January 2000, criminalized squeegeers ${ }^{10}$ and panhandlers for working on city streets (Esmonde 2002). From a neoliberal perspective, this type of work is not acceptable because it is not regulated by the market, does not contribute to Ontario's economy and, hence, is problematic. For individuals who relied on this income for survival, however, the new law was a huge barrier because it pushed them further in poverty. The rhetoric used to construct the Safe Streets Act made street-workers appear dangerous, aggressive, and a threat to the safety of the public (Esmonde 2002). The Act was successful in creating a culture of fear and mistrust about the homeless population and, more generally, the poor (Esmonde 2002).

The changes Harris made under the new radical neoliberal agenda led to a dramatic increase in Ontario's poverty rates, rising from $7.8 \%$ in 1989 to $14 \%$ in 1996, the highest it had ever been (Sharma 2012). Marginalized groups, such as the ones targeted as the undeserving poor, experienced even higher rates of poverty. Racialized groups, for example, saw a sharp increase in poverty rates in comparison to the rest of the population, increasing from 24.6\% to 35.8\% (Hudson and Graefe 2012). In fact, Sharma (2012) found that in 1996 the risk of an ethnic minority experiencing poverty within Ontario was $154 \%$ greater than the general public. Homelessness increased staggeringly because of the changes made to tenants' rights and reductions in affordable housing (Maxwell 2009). Moreover, 40\% of individuals falling below the low-income threshold were identified as having a disability (Hudson and Graefe 2012). Evidently, the policies created and implemented by the Harris administration failed to serve marginalized communities. The Progressive Conservatives perpetuated, through gendered, classist, and ableist discourses, the idea that poverty is an individual problem that each person is responsible for on their own accord (Coulter 2009).

Harris' policy decisions and provincial budget were not without opposition. Antipoverty activists and union workers were vocal about their disapproval of the neoliberal agenda and the ever-shrinking social safety-net meant to support low-income families (Fanelli and Thomas 2011). The Ontario Federation of Labour (OFL) organized the first series of general strikes earlyon during Harris' tenure; these demonstrations were called Days of Action and were the unions' way of responding to the assault that Harris had waged against the poor (Fanelli and Thomas 2011; Maxwell 2009). Between 1995 and 1998 a total of eleven Days of Action were held across different communities within Ontario wherein public sector workers, faith groups, labour unions, and concerned members of the public joined forces and rallied against the neoliberal policies being implemented (Maxwell 2009). The Harris government was notably unreceptive to protests, claiming that activists had their own hidden motives for the demonstrations (Maxwell 2009). Harris made it a point to reduce citizen engagement by restricting public participation in policymaking consultations; he denounced the idea of a citizen-driven method of policy construction (Kozolanka 2010). His policies, hence, had little input from the voices of the marginalized and powerless, favouring instead the needs of the wealthy segments of the population such as the private sector, business owners, and corporations (Kozolanka 2010). Nevertheless, 
the outcome of these strikes helped build solidarity and a public recognition for change in Ontario's social policy agenda.

\subsection{Neoliberalism and the Illusion of Social Progression: 2003 to 2020}

Harris was succeeded by Ernie Eves, another Progressive Conservative, between 2002 and 2003 who continued the agenda of economic austerity (Coulter 2009). Following Eves brief time in office, Dalton McGuinty's Liberals were elected into Ontario's legislature in 2003 amid a growing backlash against the Progressive Conservatives for their cuts to social programs (Fanelli and Thomas 2011). The Liberals had run on a campaign platform that promised to maintain public services without increasing taxes, a direction that appealed to the public. It was also during McGuinty's tenure that the government took concrete steps towards creating the province's first poverty reduction strategy. Though the Liberal agenda appeared more progressive than that of their Conservative counterparts, neoliberal policy-making did not wane under the new government's mandate. Much of the Liberal party's' policy focus remained on catering to the needs of the middle-class electorate in order to maintain a strong voter base, rather than to address the needs of marginalized groups who had less political power (Hudson and Graefe 2012). The notable difference between the Liberal government and the Progressive Conservatives was that the Liberals took a softer approach to neoliberal integration, one that was not as radical or aggressive as the Harris-Eves period (Coulter 2009).

During McGuinty's tenure, modest investments were made to education, health and eldercare, social assistance and municipal transfers, and there was a promise to gradually increase the minimum wage to $\$ 10.25 / \mathrm{h}$ (B. Evans 2007; Fanelli and Thomas 2011). However, the Liberal administration was criticized for selectively allocating funds to a limited number of public services, ultimately leading to the de-prioritization of other important social programs such as services for Indigenous communities, women's shelters, and housing provisions (Coulter 2009). Many low-income, marginalized, and at-risk communities relied on these programs for support (Coulter 2009). Ontarians receiving social assistance through OW or ODSP were similarly targeted by McGuinty's neoliberal agenda when the Special Diet Allowance (SDA) was eliminated in 2010 (Bonnar 2010). This needs-based allowance offered an additional $\$ 250$ per month for applicants, conditional upon medical assessment and approval (Bonnar 2010). Once demand for the supplement began to increase, the Liberals made it difficult to apply for the benefit by introducing excessive paperwork and, eventually, scrapped the initiative citing financial burden on the province (Bonnar 2010). McGuinty was also notorious for privatizing health services formerly covered under the Ontario Health Insurance Plan (OHIP), making it difficult for families with low incomes to afford them. For example, eye exams and other optometry services, dental care, physical therapy, and chiropractic services were all delisted from provincial coverage (Coulter 2009). In addition, an annual health premium, ranging from $\$ 60$ to $\$ 900$, was imposed on all Ontarians during McGuinty's tenure (Fanelli and Thomas 2011). However, unlike Harris' outspoken adherence to fiscal conservatism and principals of neoliberalism, the McGuinty administration maintained a subtlety in their approach to integrating these tenets. Language and discourse served as powerful tools through which the provincial government was able to incorporate neoliberal values into political rhetoric (see Table 2 for a summary of the provincial transition to neoliberalism). 
Table 2. Summary of Ontario's Premiers in power at the provincial level during the Keynesian period to current neoliberal times (Albert and Kirwin 2006; Harvey 2005; Parliament of Canada 2016b).

\begin{tabular}{|c|c|c|c|}
\hline Ontario's Premier & Political Party in Power & Time Period & Political Ideology and Impact on Social Policy \\
\hline $\begin{array}{l}\text { 1. George Drew } \\
\text { 2. Thomas Kennedy } \\
\text { 3. Leslie Frost } \\
\text { 4. John Robarts } \\
\text { 5. Bill Davis } \\
\text { 6. Frank Miller }\end{array}$ & Progressive Conservative & 1943-1985 & $\begin{array}{l}\text { Post-World War II period } \\
\text { Marked by a balance between conservative } \\
\text { values and Keynesian style social } \\
\text { investments } \\
\text { Period of the "Big Blue Machine" because } \\
\text { of the extended reign of the PCs }\end{array}$ \\
\hline David Peterson & Liberal & 1985-1990 & Neoliberal period begins \\
\hline Bob Rae & New Democratic Party & 1990-1995 & Period of subtle neoliberal integration \\
\hline Mike Harris & Progressive Conservative & 1995-2002 & \multirow{2}{*}{ Period of aggressive neoliberal integration } \\
\hline Ernie Eves & Progressive Conservative & $2002-2003$ & \\
\hline Dalton McGuinty & Liberal & $2003-2013$ & \multirow{2}{*}{ Period of subtle neoliberal integration } \\
\hline Kathleen Wynn & Liberal & 2013-2018 & \\
\hline Doug Ford & Progressive Conservative & 2018-present & Period of aggressive neoliberal integration \\
\hline
\end{tabular}

Coulter (2009) examined the influence of neoliberal ideology on policy discourse during McGuinty's tenure. Using data collected from Ontario's provincial legislature between 2004 and 2005, Coulter (2009) conducted document analyses, participant observations, and interviews with political workers, to measure the extent of neoliberal integration on social policies and programs. The study found that the Liberal government used specific vocabulary and strategic language combinations to merge neoliberalism within their policies, while sustaining the illusion of a centrist and progressive political agenda (Coulter 2009). More specifically, it was found that the Liberals used "linguistic combinations [that] pair[ed] collectivist, public service vocabulary with terms and evaluative criteria from the for-profit sector" (Coulter 2009, p. 193). Terminology popular in neoliberal rhetoric, such as "prudent management", "accountability", "individual achievement", "ladder of opportunity", and "fiscal responsibility", were frequently found in policy documents and provincial budgets during McGuinty's tenure (Coulter 2009). Thus, Coulter (2009) concluded that it was the fusing of for-profit interests and language to public services and spaces that aided in the normalization of neoliberalism in Ontario's political arena (Coulter 2009). The fusion of socially progressive language with neoliberal ideologies played an influential role in shaping Ontario's poverty reduction strategy documents.

\section{The Origins of Ontario's Poverty Reduction Strategy \\ 5.1. Addressing Poverty in Neoliberal Times}

The story of Ontario's poverty reduction strategy begins in 2007 during McGuinty's bid for a second term as the province's Premier. Leading up to the election, pressure had been mounting for the establishment of a provincial poverty reduction plan. With Ontario under the threat of a major recession, grassroots movements and not-for-profit organizations worked diligently to get poverty on to the political agenda (Fernando and Earle 2011). Public events were held, petitions were organized, and open letters were drafted to push for a plan that had concrete targets and timelines (Maxwell 2009). The main advocates involved in these rallies included the Ontario Coalition Against Poverty (OCAP), Social Planning Network of Ontario (SPNO), the C. D. Howe Institute, the Maytree Foundation, the Tamarack Institute and its Vibrant Communities Initiative, Ontario Federation of Labour (OFL), the Income Security Advocacy Centre (ISAC), and the Metcalfe Foundation, amongst many others (Barata and Murphy 2011; Hudson and Graefe 2012). Upon McGuinty's re-election into the legislature he promised to establish a poverty reduction strategy with concrete targets and measures, a move which was a welcome surprise for many Ontarians given the government's weak track record for social policy reform (Hudson and Graefe 2012). Within the first year of his return to office, McGuinty established a Special Cabinet-level Committee on poverty reduction and held consultations across the province to identify 
issues to address within the strategy. The official policy document entitled Breaking the Cycle: Ontario's Poverty Reduction Strategy was released on 4 December 2008 (Barata and Murphy 2011).

\subsection{Mobilizing Change through Grassroots Movements}

Prior to the 2007 provincial election, anti-poverty advocates had found few opportunities to advance a genuine dialogue about poverty reduction with the government due to the influence of neoliberalist beliefs on Ontario's social policy arena. Even though neoliberalism continued to factor prominently into policy language and discourse during McGuinty's tenure, the difference was that there was now an increased push from grassroots movements and non-governmental organizations to address poverty collectively and collaboratively. One of the earliest examples of a successful social partnership was between the Atkinson Charitable Foundation, St. Christopher House, and a renowned consulting firm, which resulted in the formation of the Modernizing Income Security for Working Age Adults (MISWAA) Task Force (Barata and Murphy 2011). This coalition sponsored a report about income insecurity and social assistance, which later spearheaded the development of Ontario's Child Benefit (OCB) in 2007. The introduction of the OCB was a significant new investment for Ontario's low-income families since the federal child benefits were created a decade earlier (Barata and Murphy 2011). It provided families with financial support to provide their children with essential goods such as food and shelter. The OCB served as the cornerstone upon which Ontario's poverty reduction strategy was designed (Barata and Murphy 2011).

As the anti-poverty movement gained momentum, several organizations joined forces to form the 25in5 Network for Poverty Reduction. The 25in 5 steering committee included the key players involved in the MISWAA report, in addition to the Wellesley Institute, the Colour of Poverty, United Way Toronto, the Interfaith Social Assistance Reform Coalition (ISARC), Ontario Campaign 2000, Daily Bread Food Bank, the Ontario Coalition for Social Justice (OCSJ), Voices from the Street, and many aforementioned organizations (Hudson and Graefe 2012). This committee acted as a vehicle to engage the government in conversation about poverty and played an important role in influencing the design of Ontario's official poverty reduction strategy. The primary thrust of this group was to set a goal of reducing poverty by $25 \%$ over 5 years and $50 \%$ over 10 years (Hudson and Graefe 2012). This poverty reduction target was adopted by the province within their strategy. The 25in5 Network helped establish a channel through which organizations from varying orientations with different policy concerns could find alignment and present their concerns collaboratively to the government (Barata and Murphy 2011).

The key piece that brought these diverse organizations together was the identification of a common framework of demands that all organizations felt needed attention. These included upgrading living conditions of low-income Ontarians, promoting sustainable employment and livable incomes, increased access to essential social resources, and a focus on assisting children of low-income families (Hudson and Graefe 2012). Furthermore, $25 \mathrm{in} 5$ objected to the means-tested nature of social assistance provision, recommending that the limit on personal assets be raised for those receiving OW/ODSP or legal aid to allow families to accumulate savings ${ }^{11}$ (Hudson and Graefe 2012). They also suggested extending medical coverage to include full dental, vision, and pharmaceuticals, as well as public transportation subsidies for low-income workers (Hudson and Graefe 2012). However, not all recommendations were enthusiastically welcomed by McGuinty's administration. The recommendations that were eventually adopted by the province were still heavily shaped by neoliberal ideals rather than the needs of the marginalized communities.

\subsection{Drafting the Poverty Reduction Strategy: Consulting, Designing, and Legislating}

The anti-poverty movement played a major role in mobilizing and informing Ontario's poverty reduction agenda. To supplement feedback from these sources, McGuinty and the Special Cabinet Committee on Poverty Reduction held consultations across the province 
including 14 roundtable discussions, ${ }^{12}$ website responses, conversations over telephone, letters, and over 75 community meetings in which 44 MPPs participated (Clutterbuck 2008; Government of Ontario 2008). Meetings took place as community-led sessions, public forums and town hall meetings (Clutterbuck 2008). Ontario's Breaking the Cycle strategy document makes reference to the results of these consultations numerous times, albeit in a very generic manner. Given the lack of transparency of the consultation process and the ambiguous discussion of the findings, it is difficult to conclude how strongly, or in which ways, the final policy document was informed by the results. Nevertheless, the inclusion of community voices within the strategy signifies the importance of community engagement and is an exemplary model for policy drafting in the future.

The final strategy document called Breaking the Cycle: Ontario's Poverty Reduction Strategy was officially released in December 2008. The 42-page strategy identified an overall target of reducing the number of children living in poverty by $25 \%$ over five years and identified key areas of action that the government would focus on. Over its nine content chapters, the document identified a collection of programs and investments that the provincial government would make to reach the set target. The reception of the strategy was mixed (Maxwell 2009). Many advocacy groups that were part of the anti-poverty grassroots movement praised the government for taking the first steps towards poverty reduction. However, several other groups and politicians from the opposition were quick to note that the strategy did not sufficiently cover the needs of certain populations who were at an increased risk of poverty, such as persons with disabilities, Indigenous populations, lone parents, immigrants, and the elderly (Maxwell 2009). The strategy has been criticized by academics for being tightly circumscribed within neoliberal ideals (Fernando and Earle 2011). The influence of neoliberalism is apparent in the narrow focus of the strategy, the language used to describe the recommendations, and the types of investments that were proposed. The emphasis placed on children as future investments for Ontario's economy, for example, was problematic because it ignored other age groups experiencing poverty. Moreover, the fixation on the employability of Ontarians also left much to be desired with respect to social investments and supports available to those living in poverty. Important topics such as food security, living conditions and access to services received little coverage (Government of Ontario 2008).

On 6 May 2009 the Liberals ratified the Poverty Reduction Act (Legislative Assembly of Ontario 2009, chp. 10) which made the province's commitment to poverty reduction legally binding (Mendell 2009). The Act was inspired, in-part, by the legislative steps that Quebec had taken to combat poverty and social exclusion in $2002^{13}$ (Mendell 2009). The purpose of the Act was to ensure that mechanisms were established to support a sustained long-term goal of poverty reduction within Ontario, and to ensure a standardized set of directives were created to regulate subsequent strategies. The Act highlighted eight guiding principles that the strategy's recommendations were expected to abide by. These included the importance of all Ontarians, recognition of diversity, importance of communities, family support, involvement, respect, commitment and cooperation, and importance of the third sector (Legislative Assembly of Ontario 2009, chp. 10). Furthermore, there were nine formatting rules outlined in the Act that the strategy was required to follow, such as the publication of annual progress reports on the achievements of the strategy. It also required that the strategy be renewed with updated targets every five years.

The second renewal of the strategy was released on 3 September 2014 and was entitled Realizing Our Potential: Ontario's Poverty Reduction Strategy (Government of Ontario 2014). This 49-page plan was introduced under Kathleen Wynne, the incumbent Liberal Premier of Ontario after McGuinty's resignation in 2013, and Deputy Premier Deb Mathews (Denette 2013; Government of Ontario 2008). The document contained five content chapters focused on revisiting the 2008 strategy, poverty experienced by children and youth, employment and income security, eradicating homelessness, and evidence-based social policy. The consultation process for the second installment of the strategy was similar to Breaking the Cycle (2008), wherein a Technical Advisory Group was established to travel across 
the province listening to the opinions of Ontarians about poverty reduction and their views on the previous strategy (Government of Ontario 2014). Over 2000 responses were received through online surveys and market research, 65 formal submissions from external organizations were collected, and more than 800 individuals participated in the consultations (Government of Ontario 2014).

With respect to the design and content of the renewed strategy, there was considerable overlap with Breaking the Cycle (2008), including the overall target of the strategy, the measures used to track progress, and similarities between the areas of action. There was some variation, however, in the types of programs and initiatives that were proposed, such as a greater emphasis on ending homelessness. The second installment of the poverty reduction plan, nevertheless, continued to echo neoliberal sentiments with the focus remaining on employment and children (Government of Ontario 2014). Therefore, although Ontario's implementation of a concrete poverty reduction strategy appears to be a progressive step towards stronger social policies, it remains deeply entrenched within neoliberal thought.

\section{Poverty Reduction in Present-Day Ontario: Reverting to Aggressive Neoliberal Policies}

Approximately one year ahead of the anticipated third installment of Ontario's poverty reduction strategy, significant changes to the political arena raised questions about its future within the province. On 29 June 2018 Progressive Conservative Party leader Doug Ford became the new Premier of Ontario, ringing in a new era of neoliberal austerity (Collier 2018). One of the first reforms Ford and his constituents levied against low-income Ontarians was to cut back on the promised 3\% increase to social security to a $1.5 \%$ increase (ALPHA 2018; Grinspun 2018). Concerned social advocacy groups note that this increase fails to cover the rate of inflation within the province, which sits at $2.5 \%$, forcing vulnerable populations into precarious situations where they are unable to afford food or shelter (ALPHA 2018; Grinspun 2018). The Ford administration also made the decision to cancel Ontario's Basic Income Pilot (OBIP) project which was propositioned in June 2016 as part of Ontario's poverty reduction initiative. The goal of OBIP was to provide randomly selected individuals within designated geographical locations ${ }^{14}$ a guaranteed income with the goal of measuring outcomes related to: food security, mental health, healthcare, housing stability and employment (Grinspun 2018; Government of Ontario 2017). The results of this project would have provided important evidence to inform social policy creation within Ontario. Other proposed, and implemented, claw-backs under the Ford regime included: a minimum wage freeze at $\$ 14 / \mathrm{h}$ until 2020, weakened worker rights (e.g., removing paid sick days), removal of rent controls in the midst of the province's affordable housing crisis, suspending the creation of overdose prevention sites and harm reduction programs, changes to prescription coverage under Ontario Health Insurance Plan (OHIP), and cancellation/reduction of funding for universities and a variety of social programs in Ontario (e.g., Indigenous Culture Fund) (Armstrong 2018; Beattie 2018; Canadian AIDS Society 2018; Collier 2018).

The policies executed by the Ford administration beginning in 2018 are reminiscent of those during the Harris' "Common Sense Revolution" wherein individuals living in poverty were frequently vilified and criminalized rather than supported by the provincial social safety net. It is unsurprising, therefore, that all documentation related to Ontario's poverty reduction strategy, including core documents and annual reports, were archived online upon Ford's succession in office, and available only as social artefacts for research purposes (Government of Ontario 2018). This symbolic elimination of the poverty reduction strategy serves as an indication that the most vulnerable members of society had little place on Premier Ford's political agenda. Further, it demonstrated the aggressive neoliberal policies that were on the horizon for Ontario in 2019 and beyond (see Table 2). Predictably, in the third and most recent iteration of the poverty reduction strategy-the first plan to be released under the Ford administration called Building a Strong Foundation for Success: Reducing Poverty in Ontario (2020-2025)—strong neoliberal influences can be 
easily observed and remain deeply entrenched within the policy (Government of Ontario 2020). For example, the principal aim of the current strategy focuses on "moving social assistance recipients into meaningful employment" (Government of Ontario 2020, p. 1); in other words, as is characteristic of classic neoliberalism, the policy attempts to de-center the government's role towards fiscally supporting Ontarians through a universal social safety net, and placing the responsibility squarely on the shoulders of already-impoverished Ontarians instead (Government of Ontario 2020). It is heartening, however, to see the work of social advocacy groups in opposing the implementation of these neoliberal policies and their push to defining poverty as an intersectional phenomenon that impacts a diverse population of Ontarians ${ }^{15}$ and one that requires an equally multidimensional response.

\section{Conclusions}

The purpose of undertaking this descriptive case study and analysis was two-fold: first, it aimed to construct a critically-informed historical and genealogical narrative defining the growth of neoliberalism in Canada and Ontario by drawing on a range of primary, secondary and grey literature. Second, the intent of this paper was to better understand the impact of neoliberalism on the construction of poverty policies within the province and the role that social advocacy groups and grassroots movements played in pushing for a poverty reduction strategy. The results of this study are significant for policy-makers, scholars, researchers and advocacy groups to recognize and critically question the influence of political ideologies on the construction of public policies in general. It is essential to question and deconstruct public policies to ensure that the most responsive policies are created within any jurisdiction. Action needs to be taken to dismantle systematic inequities and hierarchies of domination that are perpetuated through hegemonic neoliberal discourses.

It was found that within Canada and Ontario the growth of neoliberalism has been ongoing since the 1980s, with spikes of aggressive implementation followed by periods of subtle neoliberal influence. These trends have had significant impacts on how the provincial government in Ontario has chosen to tackle poverty. Grassroots movements and social advocacy groups have been influential forces in the implementation of the two installments of Ontario's poverty reduction strategies: Breaking the Cycle (2008) and Realizing Our Potential (2014). Nevertheless, these strategies were also deeply embedded within neoliberal principles. The current political climate signals a return to aggressive neoliberalism, threatening the very core of poverty reduction strategies within the province.

Funding: This research received no external funding.

Acknowledgments: I am thankful to my supervisors, Dennis Raphael and Nancy Viva Davis Halifax (York University), for their invaluable input and advice during the writing of an earlier version of this manuscript. This paper builds on research conducted as part of my master's project and would not have been possible without the support of York University's School of Health Policy and Management. Finally, I would like to express my sincere gratitude to the editors and three anonymous reviewers for their suggestions and feedback.

Conflicts of Interest: The author declares no conflict of interest.

\section{Notes}

1 It should be noted that the critical theory paradigm is not a monolithic analytical lens,. There exist multiple branches, traditions, and iterations of critical theory informed by various schools of thought. Critical theorists draw from the eclectic works of diverse scholars including Karl Marx, neo-Marxist theorists of the Frankfurt School such as Max Horkheimer and Theodor W. Adorno, Michel Foucault, Immanuel Kant, Antonio Gramsci, Stuart Hall, Paulo Freire, Franz Fanon, Simone de Beauvoir, Patricia Hill Collins, Kimberlé Crenshaw, Gayatri Chakravorty Spivak, amongst many others (see Fuchs 2020; Kellner 1990; Kincheloe et al. 2018).

2 Hegemony, in the Gramscian sense, is power that operates through the consent of the governed. In other words, hegemonic values are perpetuated and reinforced through social interactions, relationships, structures, and institutions, rather than through coercion or force, which ultimately helps establish hierarchies of domination within society (see Thomas 2012; Garlitz and 
Zompetti 2021). Hegemonic ideas also ebb-and-flow over time, according to historical moments and contexts (Garlitz and Zompetti 2021).

3 Although neoliberalism has been described here in very clear-cut and absolute terms, it is an ideology that is much more complex, dynamic, and variegated than explicated within the current discussion (Fletcher 2019). Neoliberal thought can manifest differently within diverse contexts such that specific principles are emphasized in certain spaces and minimized in others. For the purpose of this paper, I approach the concept of neoliberalism from the angle of Marxist-derived critical theory; thus, framing the direction of the analysis presented and the definitions adopted within this paper in kind. It should be noted that the multifaceted nature of neoliberalism has been widely discussed and extensively debated elsewhere within the literature (see Brenner et al. 2010; Castree 2010; Ferguson 2010; Jessop 2019; Springer 2012; Venugopal 2015). An in-depth and comprehensive exploration of neoliberalism's multiple definitions and conceptualizations, which are all firmly rooted within particular paradigmatic traditions and theoretical frameworks, falls beyond the scope of this paper's focus.

4 Targeted social programs are provided on a means-tested basis, whereas universal programs are accessible to everyone irrespective of a person's income or assets (P. Evans 1996).

5 Transfer payments redistribute tax revenues to provincial governments and individuals vis-à-vis direct cash payments offered on either a conditional or unconditional basis. They are used to fund social services and provide financial support.

6 Social planning councils are a network of nonprofit community-based organizations that are concerned with social policy issues, social planning, advocacy, and research. They run on a mandate of social justice, community development, and community mobilization. The establishment of these councils was spearheaded by the Canadian Council of Social Development (CCSD) in the 1970s. They can now be found across Canada, with a significant concentration in Ontario. The main network in Ontario is called the Social Planning Network of Ontario (SPNO) and has played a key role in gauging anti-poverty initiatives (Maxwell 2009). All social planning councils are collaborative and interactive, sharing ideas through conferences and meetings (Canadian Council on Social Development 2013).

7 Between 1966 and 1995, the federal government had two mechanisms of sharing tax revenues amongst the provinces. The first method was through Established Programs Financing (EPF) which transferred predetermined block payments to each province in order to support healthcare and education. The EPF was distributed equally to each province on a per capita basis. The second method was through the Canada Assistance Plan (CAP) which provided funding based on a cost-sharing model where the federal government equally matched the amount spent by each province for programs such as social assistance, social housing, child welfare, civil legal aid, and community programs such as child care, women's counseling and shelter services. In 1990, under Mulroney's neoliberal agenda, a limit was implemented on the CAP for Ontario, Alberta, and British Columbia. In 1995 the CAP was completely replaced with Canada Health and Social Transfer (CHST). The CHST eliminated the 50-50 matching of funds that characterized the CAP, instead providing a per capita block payment which was generally lower than what the CAP provided. The CHST was used to fund Medicare, post-secondary education, welfare and social services (Department of Finance Canada 2014; Maxwell 2009).

8 Historically, during their 42 years in power, the Progressive Conservatives had operated from the political center. Political commentators called their approach 'Red Toryism' because it was characterized by policies that took a more liberal or mildly socialist stance on certain fiscal and social issues. In other words, 'Red Tories' are less conservative than their 'Blue Tory' counterparts who are staunch believers in free enterprise, tax reduction and corporate welfare. Mike Harris' government falls into the latter category of Blue Tory (Fanelli and Thomas 2011).

9 A single individual under Harris' reformed social assistance plan received $\$ 520$ per month, out of which a maximum of $\$ 325$ was allocated towards shelter (including rent and utilities). The remaining $\$ 195$ was to be used for personal expenses such as food, clothing, and other items for survival. The average rent during this time (within urban dwellings like Toronto) was much higher than was allocated by the province (Esmonde 2002).

10 Individuals who wash vehicle windshields in exchange for change, found mainly on busy streets in urban centers (Esmonde 2002).

11 The $25 \mathrm{in} 5$ network recommended raising the limit for personal assets to $\$ 5000$ for single people and $\$ 10,000$ for families and people with disabilities (Hudson and Graefe 2012).

12 Roundtable discussions were convened by Deb Matthews who was, at that time, Chair of the Cabinet Committee of Poverty reduction and the Minister of Child and Youth Services (Clutterbuck 2008; Government of Ontario 2008).

13 On 13 December 2002, Quebec became the first province to introduce legislation that focused on combatting poverty and social exclusion (Mendell 2009). They were also the first to establish a provincial poverty reduction plan in all of Canada, which was released in August 2002, entitled The Will to Act, The Strength to Succeed. National Strategy to Combat Poverty and Social Exclusion (Mendell 2009). One of the key strengths of Quebec's plan was its multidimensional approach to poverty, taking into account the dimensions of social exclusion. Quebec's provincial government also developed a 15 member advisory committee on poverty reduction/social exclusion and established a research center dedicated to evaluating the progress of the strategy as well as making innovations in poverty indicators and measures (Mendell 2009). Quebec's policy inspired other provinces to follow suit, including Newfoundland and Labrador and Ontario (Mendell 2009). 
The geographical areas for the pilot study were determined based on urban/ rural location, demographics, economic need and access to social services. Areas chosen include Hamilton, Brantford, Brant County, Lindsay, and Thunderbay and surrounding area (Government of Ontario 2017).

15 Inclusive of age, race, ethnicity, socioeconomic status, gender, sexual orientation, ability, geographical location, educational attainment or employment status.

\section{References}

Albert, Jim, and Bill Kirwin. 2006. Social and welfare services. The Canadian Encyclopedia. Available online: https://www. thecanadianencyclopedia.ca/en/article/social-and-welfare-services (accessed on 18 December 2021).

Armstrong, Tim. 2018. Premier Ford's Troublesome Track Record. Toronto Star. December 17. Available online: https://www.thestar. com/opinion/contributors/2018/12/17/premier-fords-troublesome-track-record.html (accessed on 18 December 2021).

Association of Local Public Health Agencies (ALPHA). 2018. Re: Alpha Resolution AlS-4, Public Health Support for a Basic Income Guarantee [Open Letter]. August 2. Available online: https://www.rcdhu.com/wp-content/uploads/2018/10/04.Correspondence.pdf (accessed on 18 December 2021).

Azmanova, Albena. 2020. Capitalism on Edge: How Fighting Precarity Can Achieve Radical Change without Crisis or Utopia. New York: Columbia University Press. [CrossRef]

Barata, Pedro, and Colette Murphy. 2011. Foundations for Social Change: Reflections on Ontario's Poverty Reduction Strategy. Canadian Review of Social Policy/Revue Canadienne de Politique Sociale 65/66: 16-30. Available online: https://crsp.journals.yorku. ca/index.php/crsp/article/view/35192 (accessed on 18 December 2021).

Baxter, Pamela, and Susan Jack. 2008. Qualitative Case Study Methodology: Study design and implementation for novice researchers. The Qualitative Report 13: 544-59. [CrossRef]

Beattie, Samantha. 2018. The Winners and Losers of Ontario Premier Doug Ford's Spending Cuts So Far. Huffpost Canada. December 21. Available online: https://www.huffingtonpost.ca/2018/12/21/doug-ford-cuts_a_23624751/ (accessed on 18 December 2021).

Bierman, Arlene S., Farah Ahmad, and Farah N. Mawani. 2009. Gender, migration and health. In Racialized Migrant Women in Canada: Essays on Health, Violence and Equity. Edited by Vijay Agnew. Toronto: University of Toronto Press, pp. 98-136.

Bonnar, John. 2010. Timeline: Ontario Eliminates Special Diet Allowance for Social Assistance Recipients. Rabble. March 28. Available online: http:/ / rabble.ca/blogs/bloggers/johnbon/2010/03/timeline-ontario-eliminates-special-diet-allowance-socialassistance (accessed on 18 December 2021).

Brenner, Neil, Jamie Peck, and Nik Theodore. 2010. Variegated neoliberalization: Geographies, modalities, pathways. Global Networks 10: 182-222. [CrossRef]

Canadian AIDS Society. 2018. Support Life-Saving Supervised Consumption and Overdose Prevention Sites: Open Letter to Premier Doug Ford and Health Minister Christine Elliott [Open Letter]. August 30. Available online: https://www.cdnaids.ca/wpcontent/uploads/Open-Letter-re-SCS-and-OPS_Ontario_FINAL.pdf (accessed on 18 December 2021).

Canadian Council on Social Development. 2013. Social Development by Design. Available online: http://www.ccsd.ca/images/docs/ CCSD_New_Approach.pdf (accessed on 18 December 2021).

Castree, Noel. 2010. Neoliberalism and the biophysical environment: A synthesis and evaluation of the research. Environment and Society 1: 5-45. [CrossRef]

Chapell, Rosalie. 2006. Social Welfare in Canadian Society, 3rd ed. Toronto: Thomson Nelson.

Clarke, John. 2001. A Short History of OCAP. Available online: http://www.ocap.ca/archive/short_history_of_ocap.html (accessed on 27 November 2015).

Clutterbuck, Peter. 2008. Summary Report: Ontario Poverty Reduction Strategy Consultations (March to August 2008). Poverty Watch Ontario. Available online: https://povertywatchontario.ca/wp-content/uploads/sites/8/downloads/Summary-ReportOntario-Poverty-Reduction-Strategy-Consultations-Sept8-2008.pdf (accessed on 18 December 2021).

Collier, Roger. 2018. Decisions by new Ontario government worry science and health care communities. Canadian Medical Association Journal 190: E917-E918. [CrossRef]

Coulter, Kendra. 2009. Deep neoliberal integration: The production of third way politics in Ontario. Studies in Political Economy 83: 191-208. [CrossRef]

Denette, Nathan. 2013. Kathleen Wynne Sworn in as Ontario's First Female Premier, Unveils Cabinet. National Post. February 11. Available online: https:/ / nationalpost.com/news/politics/kathleen-wynne-sworn-in-as-ontarios-first-female-premier-unveilscabinet (accessed on 18 December 2021).

Denzin, Norman K., and Yvonna S. Lincoln. 2011. Introduction: The Discipline and Practice of Qualitative Research. In The Sage Handbook of Qualitative Research, 4th ed. Edited by Norman K. Denzin and Yvonna S. Lincoln. Thousand Oaks: Sage Publications, Inc, pp. 1-21.

Department of Finance Canada. 2014. History of Health and Social Transfers. Government of Canada. Available online: https://www. canada.ca/en/department-finance/programs/federal-transfers/history-health-social-transfers.html (accessed on 18 December 2021).

Dimand, Robert W. 2019. Keynesianism in Canada. In The Elgar Companion to John Maynard Keynes. Edited by Robert W. Dimand and Harald Hagemann. Northampton: Edward Elgar Publishing Inc., pp. 588-94. 
Esmonde, Jackie. 2002. Criminalizing poverty: The criminal law power and the safe streets act. Journal of Law and Social Policy 17: 63-86. Available online: https:/ / digitalcommons.osgoode.yorku.ca/jlsp/vol17/iss1/4 (accessed on 18 December 2021).

Esping-Andersen, Gøsta, ed. 1990. The Three Political Economies of the Welfare State and De-Commodification in Social Policy. In The Three Worlds of Welfare Capitalism. Princeton: Princeton University Press.

Evans, Bryan. 2007. Treading water: Four years of Ontario's liberals. The Socialist Project E-Bulletin 59: 1-6. Available online: http:/ / www.socialistproject.ca/bullet/bullet059.html (accessed on 18 December 2021).

Evans, Patricia. 1996. Eroding Canadian social welfare: The Mulroney legacy 1984-1993. In Social Fabric or Patchwork Quilt. Edited by Raymond B. Blake and Jeffery Keshen. Peterborough: Broadview Press, pp. 263-74.

Fanelli, Carlo, and Mark P. Thomas. 2011. Austerity, competitiveness and neoliberalism redux: Ontario responds to the great recession. Socialist Studies/Études Socialistes 7: 141-70. [CrossRef]

Ferguson, James. 2010. The uses of neoliberalism. Antipode 41: 166-84. [CrossRef]

Fernando, Shanti, and Benjamin Earle. 2011. Linking Poverty Reduction and Economic Recovery: Supporting community responses to austerity in Ontario. Canadian Review of Social Policy/Revue Canadienne de Politique Sociale 65/66: 31-44. Available online: https:/ / crsp.journals.yorku.ca/index.php/crsp/article/view/35197 (accessed on 18 December 2021).

Fletcher, Robert. 2019. On exactitude in social science: A multidimensional proposal for investigating articulated neoliberalization and its 'alternatives'. Ephemera: Theory and Politics in Organization 19: 537-64. Available online: http:/ /www.ephemerajournal.org/ sites/default/files/pdfs/contribution/19-3fletcher_0.pdf (accessed on 18 December 2021).

Fuchs, Christian. 2020. Towards a critical theory of communication as renewal and update of Marxist humanism in the age of digital capitalism. Journal for the Theory of Social Behaviour 50: 335-56. [CrossRef]

Garlitz, Dustin, and Joseph Zompetti. 2021. Critical theory as Post-Marxism: The Frankfurt School and beyond. Educational Philosophy and Theory, 1-8. [CrossRef]

Giroux, Henry A. 2004. The Terror of Neoliberalism: Authoritarianism and the Eclipse of Democracy. Boulder: Paradigm.

Government of Ontario. 2008. Breaking the Cycle: Ontario's Poverty Reduction Strategy (2009-2013). Ontario Cabinet Committee on Poverty Reduction. Available online: www.children.gov.on.ca/htdocs/English/documents/growingstronger/Poverty_Report_ EN.pdf (accessed on 18 December 2021).

Government of Ontario. 2014. Realizing Our Potential: Ontario's Poverty Reduction Strategy (2014-2019). Ontario Ministry Responsible for the Poverty Reduction Strategy. Available online: https:/ /www.ontario.ca/page/realizing-our-potential-ontarios-povertyreduction-strategy-2014-2019 (accessed on 18 December 2021).

Government of Ontario. 2017. Backgrounder: Ontario's Basic Income Pilot. Ministry of Children, Community and Social Services. Available online: https://news.ontario.ca/mcys/en/2017/4/ontarios-basic-income-pilot.html (accessed on 18 December 2021).

Government of Ontario. 2018. Poverty Reduction in Ontario. September 27. Available online: https://www.ontario.ca/page/povertyreduction-in-ontario (accessed on 18 December 2021).

Government of Ontario. 2020. Building a Strong Foundation for Success: Reducing Poverty in Ontario (2020-2025). December 16. Available online: https:/ / www.ontario.ca/page/building-strong-foundation-success-reducing-poverty-ontario-2020-2025\# section-7 (accessed on 18 December 2021).

Grinspun, Doris. 2018. Re: Reconsider Your Decision to Cut/Damage/Compromise Ontario's Social Safety Net [Open Letter]. Registered Nurses' Association of Ontario (RNAO), September 7. Available online: https://rnao.ca/sites/rnao-ca/files/RNAO_ Letter_to_Minister_MacLeod_-_re_Ontario_s_social_safety_net_-_Sept_7_2018.pdf (accessed on 18 December 2021).

Guest, Dennis. 2006. Social Security. The Canadian Encyclopedia. Available online: http:/ /www.thecanadianencyclopedia.ca/en/article/ social-security / (accessed on 18 December 2021).

Habibov, Nazim, and Lida Fan. 2007. Poverty reduction and social security in Canada from Mixed to Neo-Liberal welfare regimes: Estimation from household surveys. Journal of Policy Practice 6: 3-23. [CrossRef]

Harvey, David. 2005. A Brief History of Neoliberalism. Oxford: Oxford University Press. [CrossRef]

Hudson, Carol-Anne, and Peter Graefe. 2012. The Toronto Origins of Ontario's 2008 Poverty Reduction Strategy: Mobilizing Multiple Channels of Influence for Progressive Social Policy Change. Canadian Review of Social Policy/Revue Canadienne de Politique Sociale 65/66: 1-15. Available online: https://crsp.journals.yorku.ca/index.php/crsp/article/view/35221 (accessed on 18 December 2021).

Jessop, Bob. 2019. Primacy of the Economy, Primacy of the Political: Critical Theory of Neoliberalism. In Handbuch Kritische Theorie. Edited by Uwe H. Bittlingmayer, Alex Demirović and Tatjana Freytag. Wiesbaden: Springer. [CrossRef]

Kazemipur, Abdolmohammad, and Shiva S. Halli. 2001. The changing colour of poverty in Canada. Canadian Review of Sociology/Revue Canadienne de Sociologie 38: 217-38. [CrossRef]

Kellner, Douglas. 1990. Critical theory and the crisis of social theory. Sociological Perspectives 33: 11-33. [CrossRef]

Kincheloe, Joe L., Peter McLaren, Shirley R. Steinberg, and Lilia D. Monzó. 2018. Critical Pedagogy and Qualitative Research: Advancing the Bricolage. In The Sage Handbook of Qualitative Research, 5th ed. Edited by Norman K. Denzin and Yvonna S. Lincoln. Thousand Oaks: Sage Publications, Inc., pp. 235-60.

Kivisto, Peter. 2021. The social question in neoliberal times. Ethnic and Racial Studies 44: 1368-1375. [CrossRef]

Kozolanka, Kirsten. 2010. Unworthy Citizens, Poverty, and the Media: A Study in Marginalized Voices and Oppositional Communication. Studies in Political Economy 86: 55-82. [CrossRef]

Larner, Wendy. 2000. Neoliberalism: Policy, ideology, governmentality. Studies in Political Economy 63: 5-25. [CrossRef] 
Legislative Assembly of Ontario. 2009. Bill C-152: An Act Respecting a Long-Term Strategy to Reduce Poverty in Ontario, 1st Reading 25 February 2009, 39th Parliament, 1st Session, Assented to 6 May 2009. Available online: https://www.ola.org/en/legislativebusiness/bills/parliament-39/session-1/bill-152 (accessed on 18 December 2021).

Mahon, Rianne. 2008. Varieties of liberalism: Canadian social policy from the 'golden age' to the present. Social Policy and Administration 42: 342-61. [CrossRef]

Maxwell, Glynis. 2009. Poverty reduction policies and programs. In Poverty in Ontario-Failed promise and the Renewal of Hope: Ontario. Ottawa: Canadian Council on Social Development. Available online: https:/ / www.spno.ca/images/pdf/Poverty-in-OntarioReport.pdf (accessed on 18 December 2021).

McBride, Stephen. 1996. The continuing crisis of social democracy: Ontario's social contract in perspective. Studies in Political Economy 50: 65-93. [CrossRef]

McBride, Stephen. 2005. Paradigm Shift: Globalization and the Canadian State, 2nd ed. Halifax: Fernwood Books.

Mendell, Anika. 2009. Comprehensive Policies to Combat Poverty Across Canada by Province: Preliminary Document for Discussion. National Collaborating Centre for Healthy Public Policy. Available online: http:/ / www.ncchpp.ca/docs/ComprehensivePolicies_ En_Sept09.pdf (accessed on 18 December 2021).

Parliament of Canada. 2016a. Prime Ministers of Canada: Biographical Information. Available online: http:/ /www.lop.parl.gc.ca/ParlInfo/ compilations/federalgovernment/primeministers/biographical.aspx (accessed on 25 November 2015).

Parliament of Canada. 2016b. Ontario: Premiers. Available online: http://www.lop.parl.gc.ca/ParlInfo/Files/Province.aspx?Item= 01af46d5-b145-4531-84b7ea39742bd2b6andLanguage=EandMenuID=Compilations.ProvinceTerritory.aspx.MenuandSection= Premiers (accessed on 25 November 2015).

Raddon, Mary B. 2012. Financial fitness: The political and cultural economy of finance. In Power and Everyday Practices. Edited by Deborah Brock, Rebecca Raby and Mark P. Thomas. Toronto: Nelson Education, pp. 223-45.

Raphael, Dennis. 2011. Poverty in Canada: Implications for Health and Quality of Life, 2nd ed. Toronto: Canadian Scholar's Press Inc.

Ross, David P., and Clarence Lochhead. 2007. Poverty. The Canadian Encyclopedia. Available online: https:/ / www.thecanadianencyclopedia. $\mathrm{ca} / \mathrm{en} /$ article/poverty (accessed on 18 December 2021).

Sarlo, Chris, and Suzanne Walters. 2001. A New Study Says Poverty in Canada Continued to Be Overstated. The Fraser Institute. Available online: http:/ / oldfraser.lexi.net/media/media_releases/2001/20010723.html (accessed on 15 September 2015).

Schram, Sanford F. 2019. Neoliberal relations of poverty and the welfare state. In The Routledge Handbook of Critical Social Work. Edited by Stephen E. Webb. New York: Routledge, pp. 15-23.

Sharma, Raghubar D. 2012. Issues in Canada: Poverty in Canada. Don Mills: Oxford University Press.

Springer, Simon. 2012. Neoliberalism as discourse: Between Foucauldian political economy and Marxian poststructuralism. Critical Discourse Studies 9: 133-47. [CrossRef]

Steger, Manfred B., and Ravi K. Roy. 2010. Neoliberalism: A Very Short Introduction, 1st ed. Oxford: Oxford University Press. [CrossRef] Tanguay, Brian A. 1997. “Not in Ontario!” From the Social Contract to the Common Sense Revolution. In Revolution at Queen's Park: Essays on Governing Ontario. Edited by Sid Noel. Toronto: James Lorimer and Company, pp. 18-37.

Thomas, Mark P. 2012. Class, state and power: Unpacking social relations in contemporary capitalism. In Power and Everyday Practices. Edited by Deborah Brock, Rebecca Raby and Mark P. Thomas. Toronto: Nelson Education, pp. 110-32.

Venugopal, Rajesh. 2015. Neoliberalism as concept. Economy and Society 44: 165-87. [CrossRef]

White, Randall. 1999. Ontario since 1985: A Contemporary History. Toronto: EastEnd Books.

Yin, Robert K. 2003. Case Study Research: Design and Methods, 3rd ed. Thousand Oaks: Sage. 